\title{
Ecological analysis of the flora of the Kremenets Mountains National Nature Park (on the example of the mountains Divochi Skeli, Strakhova, Masliatyn, Chercha, Zamkova, Bozha)
}

\author{
Nataliia Lisova ${ }^{1}$, Myroslav Syvyj ${ }^{2}$, and Olena Volik $^{3}$ \\ ${ }^{1}$ Ternopil Volodymyr Hnatiuk National Pedagogical University, Department of Geoecology and Methods of Teaching Ecology, Ternopil, \\ 46027, Ukraine \\ ${ }^{2}$ Ternopil Volodymyr Hnatiuk National Pedagogical University, Department of Geography and its Teaching Methods, Ternopil, 46027, \\ Ukraine \\ ${ }^{3}$ University of Waterloo, Department of Geography and Environmental Management, Ontario, Canada
}

\begin{abstract}
One of the elements that ensure the sustainability of the environment is the vegetation cover. The vegetation cover contributes to the balanced functioning of ecosystems. It is the national parks rich in phytodiversity that attract the attention of scientists. The article presents an ecological analysis of the flora of the Kremenets Mountains National Park. The research was carried out in the areas of the mountains Divochi Skeli, Strakhova, Masliatyn, Chercha, Zamkova, Bozha. 10 florocoenotypes were identified in the study areas. The most numerous is the nemoral forest coenotype. The flora was analyzed for abiotic factors such as light, temperature, humidity, soil. It is these indicators that have an important impact on the formation of vegetation cover and the life processes of plants. It was found that facultative heliophytes, mesothermal plants, mesophytes, and mesotrophs predominate in the study areas. The vegetation cover has clear forest-steppe features. The classification of life forms of plants is given. Relicts and endemics are confined to steppe and calcepetrophilic areas. Flora synanthropization is observed on the study areas.
\end{abstract}

\section{Problem statement}

Vegetation cover as an autotrophic component provides energy through photosynthesis and together with the heterotrophic component is the key to the normal functioning of ecosystems.

In natural ecosystems, the vegetation cover is represented by a wide variety of species and life forms. In all ecosystems, vegetation plays a particularly important environmental and self-organizing role. It determines the spatial, visual boundaries, their structure, internal climate, soil characteristics, the set and distribution of animals and microorganisms, corrects and transforms external interactions, balances and extinguishes them and directs the energy metabolism as a whole. Green vegetation is the only generators of primary organic matter and the main energy storage, on the basis of which chemical reactions, physical and biological processes in ecosystems take place [1].

From an ecological point of view, the study of flora and vegetation cover is important, first of all, in the aspect of that specific, only inherent work, which they perform in the ecosystem as a material component. Of particular importance are the functions of the vegetation cover, such as the absorption of various substances and energy from other components of ecosystems and their synthesis into primary organic substances used for building the bodies of plants and for their internal catabolism; the release of waste products by vegetation, and with them part of the captured energy during their formation; the return to the atmosphere and soil of a part of the accumulated energy and substance during the death of organs or whole plants; transformation by vegetation cover of the properties and states of other components of ecosystems in the process of growth, absorption, accumulation and release of substances and energy [2].

All the parameters of the atmosphere that make up terrestrial ecosystems are under the control of the vegetation cover: air humidity, thermal regime, illumination, gas composition. Moreover, the higher the vegetation, the denser its thickets and the more complex the structure, the more noticeable its role in the transformation of the atmosphere. Plants also affect the thermal regime of soils, moisture, their structure, the nature of organic matter, $\mathrm{pH}$, especially its upper horizons saturated with roots. The performance of the listed functions of phytocenoses is associated with physiological processes: photosynthesis, respiration, transpiration, absorption of water, minerals, and growth. From an ecological point of view, the results of these processes and their impact on the overall ecosystem process are important $[3,4]$.

It is important the environmental stabilization value of vegetation cover, soil-protecting, water-saving, landscape, aesthetic, scientific and educational. Plants provide protection for rare populations. A rare species can 
be preserved only within the framework of certain phytocenoses, and hence the need arises for the protection of the phytogenofund and phytocenofond. Many rare and endangered plant species are consortium associated with rare representatives of the animal world. The study of their ecological and biotic properties also contribute to the preservation of populations of endangered species of fauna $[5,6]$.

Aboriginal species and their populations, which make up the natural flora, are concentrated in groups united by a common growth conditions and ecological-coenotic relationships, forming certain florocoenotypes. Such an analysis makes it possible to understand the features and confinement of certain groups of natural species to certain coenoecological niches, to show the advantage of certain floroceno-ecological complexes, their interpenetration, the genesis of the peculiarities of the formation of a certain flora. An important indicator of the ecological characteristics of phytocenoses is their relation to abiotic factors of the environment (especially light, temperature, humidity and soil), and plant life forms, which are important for plant life, since they affect the course of physiological, biochemical and other processes.

\section{Materials and research methods}

Stationary research was carried out in the most interesting and typical, in terms of phyto-diversity, mountain areas: Divochi Skeli, Strakhova, Masliatyn, Chercha, Zamkova, Bozha. The main research methods were: morphologicalgeographical and ecological-phytocenotic description of species and plant communities. The definition of the species composition and the nomenclature of Latin names are filed according to Chronicle of the nature of the Kremenets Mountains National Nature Park [7] and Keys to higher plants of Ukraine [8]. Ecological and cenotic characteristics of flora and vegetation cover according to B. V. Zaverukha [9]. Classification of life forms of plants is filed by Raunkier.

\section{Results and discussion}

On the territory of the studied mountains, we have identified the following floroceotypes: boreal forest, nemoral forest, meadow, meadow-steppe, steppe, calcepetrophilic, psamophilic, xerophytic-shrub, hygrohydro swamp, agro-ruderal (Table 1, Fig. 1).

The boreal forest florocoenotype unites 41 species $(5 \%)$, it is characterized by Holarctic species, which have areas associated with light coniferous and partially mixed coniferous-broad leaved forests: Pinus silvestris L., Juniperus communis L., Calluna vulgaris (L.) Hull., Rumex acetosella L., Pyrola media Sw., Orthylia secunda (L.) House., P. rotundifolia L., Jasione montana L., etc.

The most numerous nemoral forest coenotype includes 239 (29\%) florocenoelements: Quercus robur L., Fagus sylvatica L., Betula pendula Roth., B. klokovii Zaverucha, Carpinus betulus L., Corylus avellana L., Asarum europaeum L., Anthyrium filix-femina (L.) Roth., Stellaria holostea L., Dryopteris filix-mas (L.) Schott., Anemone nemorosa L., Hepatica nobilis Mill., Clematis recta L., Actaea spicata L., Rumex sylvestris (Lam.) Wallr., Viola reichenbachiana Jord. ex Boreau, Dentaria glandulosa Waldst et Kit., Lunaria rediviva L., Euphorbia amygdaloides L., Astragalus glycyphyllos L., Astrantia major L., Atropa bella-donna L., Laserpitium latifolium L., Scopolia carniolica Jacg., Betonica officinalis L., Convallaria majalis L., Lilium martagon L., Carex pilosa Scop., Poa nemoralis L., etc. This florocoenotype is distinguished by a certain heterogeneity typical for hornbeam-oak, oak and beech forests.

Table 1. Ecological and coenotic characteristics of the flora of the study areas.

\begin{tabular}{|l|l|c|}
\hline No. & \multicolumn{1}{|c|}{ Floroceotypes } & Number of species \\
\hline 1 & Boreal forest & 41 \\
\hline 2 & Nemoral forest & 239 \\
\hline 3 & Meadow & 123 \\
\hline 4 & Meadow-steppe & 115 \\
\hline 5 & Steppe & 18 \\
\hline 6 & Calcepetrophilic & 34 \\
\hline 7 & Psamophilic & 19 \\
\hline 8 & Xerophytic-shrub & 18 \\
\hline 9 & Hygro-hydro swamp & 53 \\
\hline 10 & Agro-ruderal & 165 \\
\hline \multicolumn{2}{|c|}{ Total } & 825 \\
\hline
\end{tabular}

The meadow florocoenotype is represented by 123 (14.9\%) florocenoelements. There are almost no relict and endemic species here, but there are many widespread species of the temperate latitude type, mainly of Holarctic and Palaearctic nature: Equisetum pratense Ehrh., Coronaria coriacea (Moench.) Schischk., Herniaria glabra L., Polygonum bistorta L., Lathyrus pratensis L., Lysimachia nummularia L., Geranium pratense L., Centaurea jacea L., Hieracium umbellatum L., Agrostis stolonifera L., Bromus mollis L., Phleum pratense L., Poa trivialis L., P. pratensis L., Festuca pratensis Huds., etc. This florocoenotype is due to the small area of meadows, large areas of the former meadows have been plowed up, some of them have been converted into pastures.

The meadow-steppe florocoenotype includes 115 (13.9\%) florocenoelements, there are accumulated species of mainly forest and steppe zonal types: Ranunculus auricomus L., Dianthus andrzejowskianus Zapal., Thalictrum flavum L., Helianthemum nummularium (L.) Mill., Filipendula vulgaris Moench., Potentilla patula Waldst., P. argentea L., Medicago procumbens Bess., Polygala comosa Schkuhr., Trifolium dubium Sibth., Galium verum L., Onosma subtinctoria Klok., Verbascum thapsus L., Salvia dumetorum Andrz., Veronica incana L., Campanula sibirica L., Poa angustifolia L., etc.

The steppe florocoenotype is small in number 18 $(2.2 \%)$ species, it consists mainly of Mediterranean and Pontic cenoelements: Euphorbia seguieriana Neck., Polygala podolica DC., Asperula cynanchica L., Aster amellus L., Trinia multicaulis Schischk., Helictotrichon desertorum (Less.) Nevski, Stipa cappilata L., S. pennata L., etc.

The calcepetrophilic florocoenotype unites 34 (4.1\%) species; it is represented by the florocenoelements of chalk, limestone, gypsum deposits and steppe groups: 
Asplenium ruta-muraria L., Minuartia aucta Klok., Aurinia saxatilis (L.) Desv., Helianthemum canum (L.) Baumg., Alysum gmelinii Jord., A. calycinum Stapf., Sempervivum ruthenicum Schnittsp. et C.B. Lehm.,
Euphorbia volhynica Bess. ex Szaf., Kulcz.,Sedum acre L., Anthyllis schiwereckii (DC) Blocki, Galium exoletum Klok., G. besseri Klok., Allium strictum Schrad., Salvia cremenecensis Bess., etc.

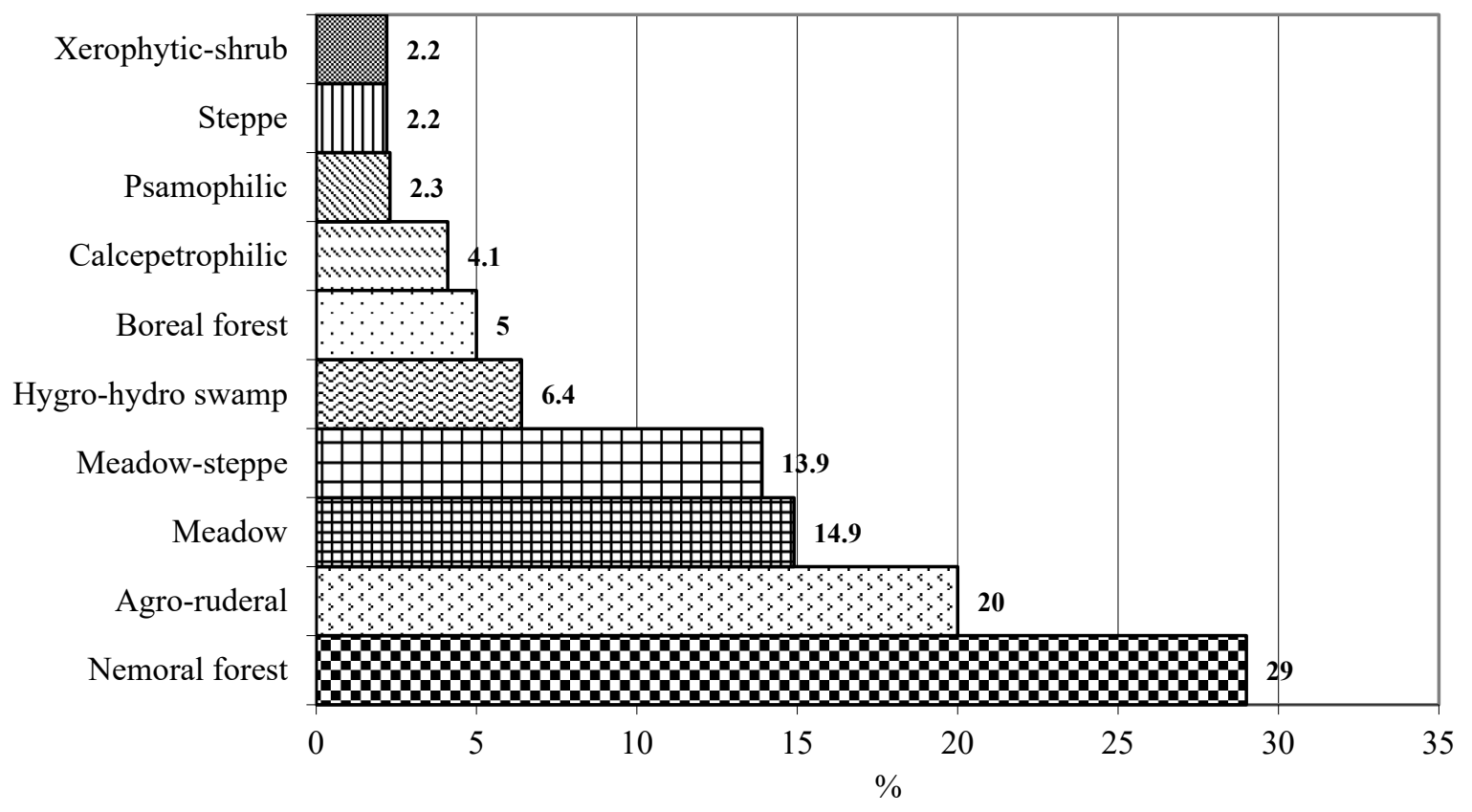

Fig. 1. The ratio of florocoenotypes in the study areas (\%).

The psamophilic florocoenotype includes 19 (2.3\%) species, these are species of sandy deposits: Gypsophila paniculata L., Cardominopsis arenosa (L.) Hayek, Astragalus onobrychis L., Potentilla arenaria Borkh., Thymus serpyllum L., Verbascum densiflorum Bertol., Onobrychis arenaria (Kit.) DC., etc.

The xerophytic-shrub florocoenotype is represented by $18(2.2 \%)$ species: Spiraea media Franz. Schmidt, Crataegus praearmata Klok., C. lipskyi Klok., Cerasus fruticosa L., Rosa livescens Bess., R. czackiana Bess., $R$. jundzillii Bess., Prunus stepposa Kotov., Padellus mahaleb (L.) Mill., etc.

The hygro-hydro swamp florocoenotype contains 53 (6.4\%) florocenoelements: Ranunculus sceleratus L., Caltha palustris L., Filipendula denudata (J. et C. Presl) Fritsch., Potentilla erecta (L.) Raeusch., Lythrum salicaria L., L. virgatum L., Juncus geniculatus Schrank., J. inflexus L., Veratrum lobelianum Bernh., Molinia careulea Maench. ex Steud., Acorus calamus L., Phragmites australis Trin. ex Steud., etc. This florocoenotype includes mainly typical species of sedge and herbaceous-sedge bogs.

The agro-ruderal florocoenotype is formed from segetal and ruderal plants. It contains $165(20 \%)$ florocenoelements: Fumaria officinalis L., F. parviflora Lam., Sinapis arvensis L., Atriplex prostrata Boucher., Thlaspi arvense L., Euphorbia helioscopia L., Erysimum cheiranthoides L., Erodium cicutarium (L.) Her., Nonea pulla (L.) DC., Strophiostoma sparsiflora Turez., Mentha arvensis L., Lycopsis arvensis L., Carduus crispus L., Solanum nigrum L., Cirsium oleraceum (L.) Scop., Bromus secalinus L., Urtica dioica L., Setaria pumila (Poir.) Schult., S. viridis (L.) Beauv., etc.
In relation to the light conditions in the study areas, we identified the following ecological groups of plants. The most numerous are facultative heliophytes (shade-tolerant ones - they can tolerate more or less shading, but grow well in the light), these are 538 species $(65.2 \%)$. These are such species as Botrychium lunaria (L.) Sw., Trollius europaeus L., Phyllitis scolopendrium (L.) Newm., Anemone nemorosa L., A. ranunculoides L., Cerastium holosteoides Fries, Corylus avellana L., 8 species of the genus Viola, Calluna vulgaris (L.) Hull, Helianthemum nummularium (L.) Mill., Rhodococcum vitis-idaea (L.) Avror., 5 species of the genus Euphorbia, 5 species of the genus Crataegus, 7 species of the genus Rosa, 4 species of the genus Inula, Galanthus nivalis L., Tragopogon major Jacq., many species of the Orchidaceae family, Calamagrostis canescens (Web.) Roth., etc.

Heliophytes (light-loving - plants of open, wellilluminated areas), their number is 256 species (31\%): Larix decidua Mill., Aquilegia vulgaris L., Pinus sylvestris L., Adonis vernalis L., Minuartia aucta Klok., Silene vulgaris (Moench) Garcke, Gypsophila paniculata L., G. fastigiata L., види родy Alyssum, Sedum acre L., S. ruprechtii (Jalas) Omelcz., Hypericum perforatum L., $H$. elegans Steph. ex Willd., Fragaria viridis Duch., F. vesca L., Scabiosa ochroleuca L., Potentilla arenaria Borkh., Scorzonera purprea L., Aster amellus L., Stipa capillata L., S. pennata L., etc.

The least numerous group is sciophytes (shade-loving - plants of the lower tiers of shady forests, caves), their number is 31 species (3.8\%): Ophioglossum vulgatum L., Cystopteris fragilis (L.) Bernh., Athyrium filix-femina (L.) Roth., Dryopteris filix-mas (L.) Schott., Pteridium aquilinum (L.) Kuhn., Asarum europaeum L., Asplenium 
ruta-muraria L., A. trichomanes L., Dentaria glandulosa Waldst. et Kit., Hepatica nobilis Mill., etc. (Fig. 2).

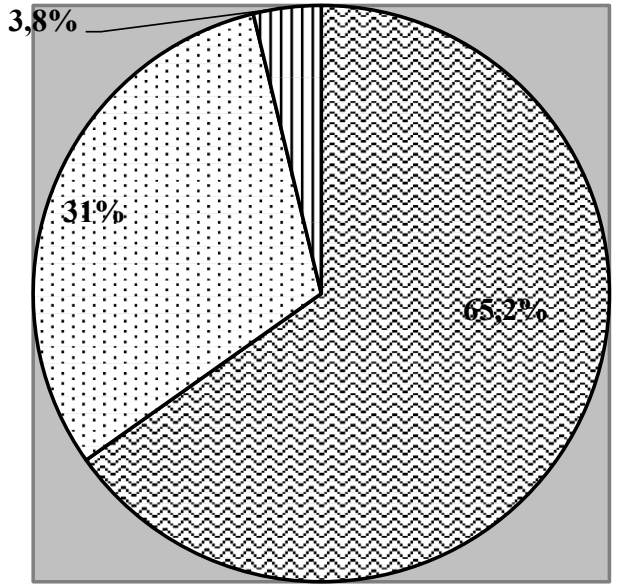

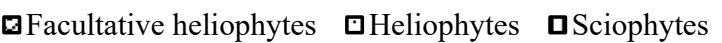

Fig. 2. The ratio of ecological groups of plants in relation to light in the study areas.

In relation to temperature, in the study area, the following groups of plants can be distinguished: mesothermal (the most common), their number is 535 species (64.8\%). These are such as Larix decidua, Actaea spicata L., Malva pusilla Smith., Daphne mezereum L., Polygala podolica DC., Staphylea pinnata L., Centaurea jacea L., Pyrethrum corymbosum (L.) Scop., Poa angustifolia L., etc.

There are 241 species of thermophilic plants (29.2\%): Helianthemum canum (L.) Baumg., Sempervivum ruthenicum Schnittsp. et C. B. Lehm., Alyssum gmelinii Jord., Euphorbia volhynica Bess. ex Szaf., Kulcz. et Pawł., Chamaecytisus austriacus (L.) Link., Galium exoletum Klok., Eryngium planum L., Jurinea pachysperma Klok., Helichrysum arenarium (L.) Moench, Festuca valesiaca Gaud., etc.

The least numerous group is cryophilic plants, there are 49 species (6\%): Orthilia secunda (L.) House, Hedera helix L., Pyrola media Sw., Lathraea squamaria L., Scirpus sylvaticus L., Orchis militaris L., Arum besseranum Schott, etc. (Fig. 3).

Depending on the humidity regime in which the plants grow, we identified the following ecological groups in the study areas (Fig. 4). The humid and moderately warm climate of this territory determines the advantage of mesophytes (plants living in conditions of medium humidity), these are 705 species $(85.4 \%)$. This includes most trees and shrubs, meadow and forest grasses: Pinus sylvestris, P. banskiana Lamb., Fagus sylvatica L., Quercus robur L., Q. petraea (Mattuschka) Liebl., Corylus avellana, Dianthus carthusianorum L. A smaller group is hygrophytes (plants that live in conditions of excessive moisture), this includes 60 species (7.3\%): Caltha palustris L., Potentilla erecte (L.) Rausch., Coronaria coriacea (Moench) Schischk. et Gorschk., Filipendula denudate (J. et C. Presl) Fritsch, Myosotis palustris L., Valeriana stolonifera Czern., Veratrum lobelianum Bernh., Pedicularis palustris L., Orchis militaris, Molinia careulea (L.) Moench., etc.

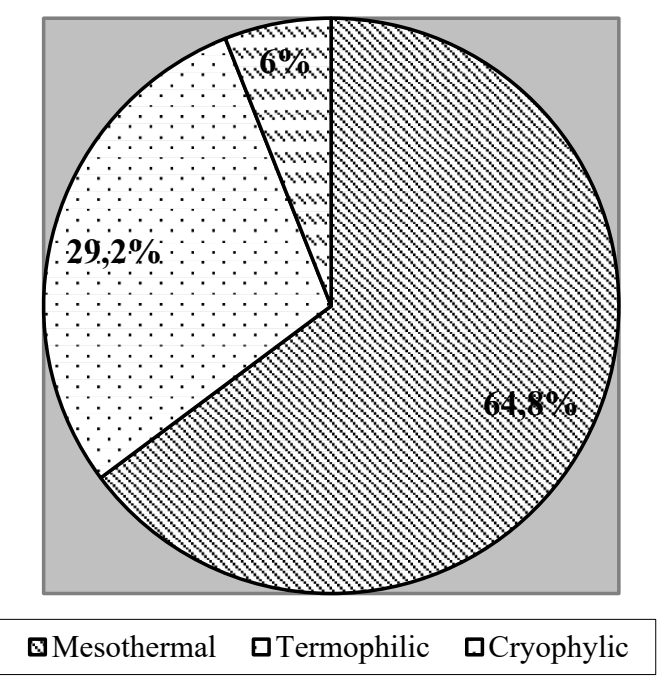

Fig. 3. The ratio of ecological groups of plants in relation to temperature in the study areas.

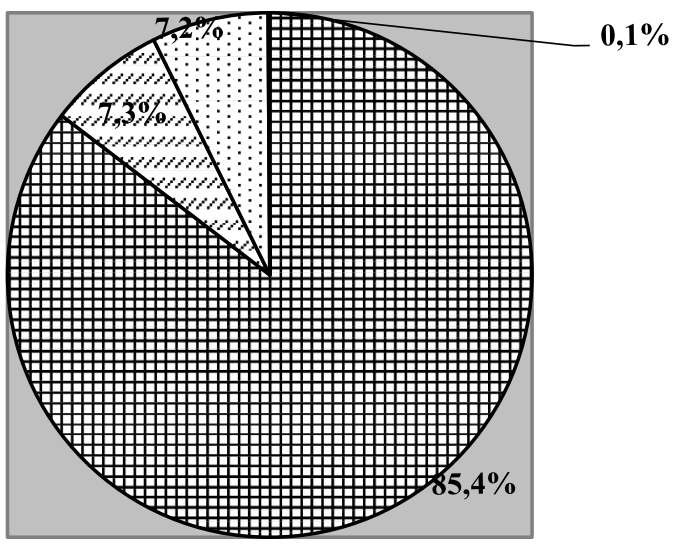

由Mesophytes $\boldsymbol{\square}$ Hygrophytes $\boldsymbol{\square}$ Xerophytes $\boldsymbol{日}$ Hydrophytes

Fig. 4. The ratio of ecological groups of plants in relation to humidity in the study areas.

Xerophytes are plants in arid areas that are able to withstand prolonged atmospheric and soil drought, 59 species (7.2\%): Minuartia aucta Klok., Alyssum gmelinii, A. calycinum L., Gypsorhila paniculata, G. fastigiata L., Sempervivum ruthenicum, Carlina biebersteinii Bernh. ex Hornem., C. vulgaris L., Sedum ruprechtii, S. acre, Asparagus verticillatus L., Stipa capillata, S. pennata, Koeleria glauca (Spreng.) DC., etc.

The least numerous group is hydrophytes includes 1 species $(0.1 \%)$. These are higher aquatic plants attached to the soil and submerged in water only with their lower part: Phragmites australis (Cav.) Trin. ex Steud.

Depending on the autoecological characteristics of plants in relation to the gross chemical composition of the soil, the following ecological groups have been identified in the study area (Fig. 5). The most numerous are mesotrophs (plants are moderately demanding of soil nutrients), this includes 368 species (44.6\%). These include: Picea abies (L.) Karst. Populus alba L., Euonymus verrucosa Scop., E. europaea L., Chaerophyllum temulum L., Tragopogon major, Laser trilobum (L.) Borkh., Lilium martagon, Ferulago 
sylvatica (Bess) Reichenb., Festuca ovina L., Bromopsis inermis (Leyss.) Holub, etc.

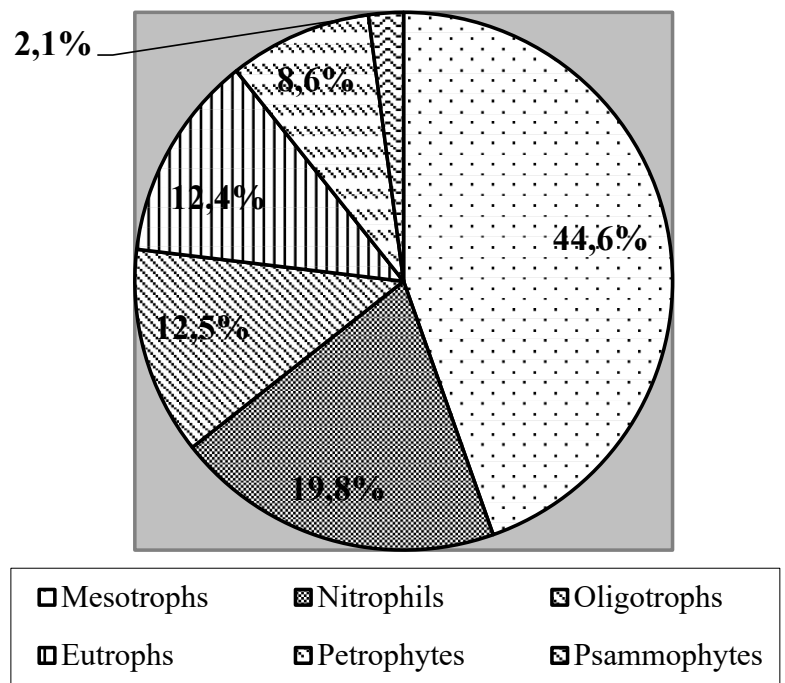

Fig. 5. The ratio of ecological groups of plants in relation to soil in the study areas

Nitrophils (plants are especially demanding for an increased nitrogen content in the soil), this includes 164 species $(19.8 \%)$, these are mainly weeds, pasture plants, species that settle in forest clearings, garbage places: Chenopodium album L., Ch. bonus henricus L., Urtica dioica L., Rumex crispus L., Chamaerion angustifolium (L.) Holub., Atriplex prostrata Boucher, Solanum dulcamara L., Heracleum sibiricum L., Elytrigia intermedia (Host.) Nevski, etc.

Oligotrophs (plants growing on barren soils), this includes 103 species (12.5\%): Pinus sylvestris, $P$. bancsiana, Orthylia secunda (L.) House, Calluna vulgaris, Pyrola media Sw., P. rotundifolia L., Ononis arvense L., Geum rivale L., Gratiola officinalis L., Epilobium hirsutum L., etc.

Eutrophs (plants growing on nutrient-rich substrates), these are 102 species (12.4\%): Fagus sylvatica, Quercus robur, Q. petraea, Q. austriaca Willd., Anemone nemorosa, A. sylvestris L., Corydalis bulbosa (L.) DC., Ficaria verna Huds., Stellaria media (L.) Vill., Daphne mezereum L., Lunaria rediviva L., etc.

A small group of petrophytes or lithophytes (plants that grow on rocks and stony places) are 71 species (8.6\%): Euphorbia volhynica, E. seguieriana Neck., Gypsophila paniculata, G. fastigiata, Minuartia aucta, Helianthemum canum, Rosa czackiana Bess., $R$. pimpinellifolia L., Cerasus fruticosa Pall., Sempervivum ruthenicum, Sedum acre, $S$. ruprechtii, Salvia cremenecensis Bess., Anthyllis schiwereckii, Astrantia major, Dracocephalum austriacum L., etc.

The least numerous group of psammophytes (plants that have a special adaptation to life on the sands) are 17 species (2.1\%): Potentilla arenaria Borkh., Cardaminopsis arenosa (L.) Hayek., Onobrychis arenaria (Kit.) DC., Trifolium arvense L., Hieracium pilosella L., Linaria genistifolia (L.) Mill., Festuca rubra L., etc.

The flora of the study areas is characterized by a variety of life forms (Fig. 6). Phanerophytes (trees and shrubs) are 74 species (9\%). Hamephytes are 25 species (3\%): Helianthemum canum, Calluna vulgaris, Rhodococcum vitis-idaea, Orthilia secunda, Pyrola media, $P$. rotundifolia, Vinca minor, Thymus serpyllum, Th. pulegioides, Th. Marchallianus., etc. Hemicryptophytes are 428 species (51.9\%): Dracocephalum austriacum, Astrantia major, Phyllitis scolopendrium, etc. Therophytes are 228 species (27.6\%): Anagallis arvensis, Xanthium strumarium ,Papaver rhoeas, P. argemone, Bidens tripartita L., Herniaria glabra L. etc. There are 70 species of cryptophytes $(8.5 \%)$. This includes most types of families Liliaceae, Iridaceae, Alliaceae, Orchidaceae.

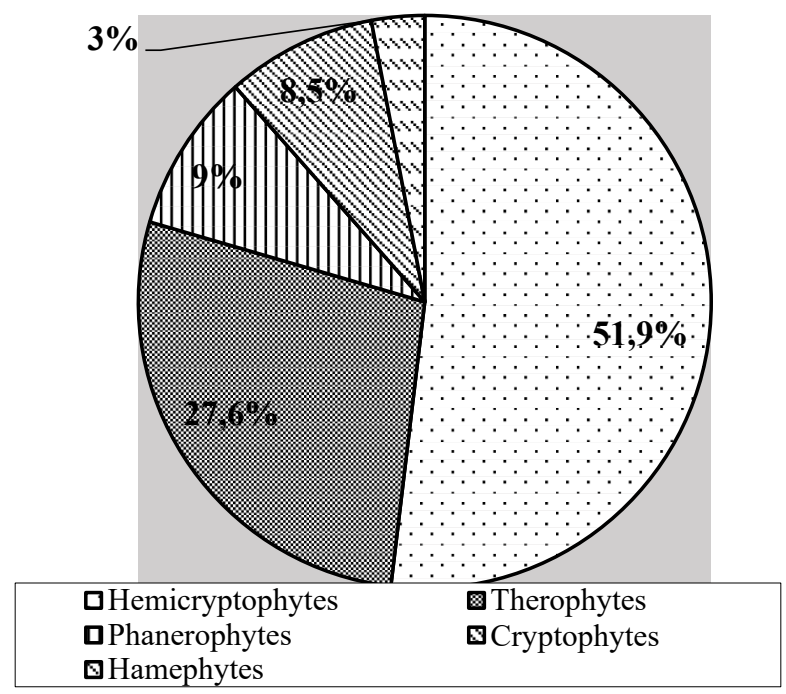

Fig. 6. The ratio of life forms of plants in the study area.

When studying the specificity of the flora of a certain region, the phenomenon of endemism is of great importance. The proportion of endemics in a particular flora characterizes the degree of individuality of a given flora. An indicator of the originality of a particular flora is the presence of a significant number of endemics. The problem of flora endemism is one of the most important indicators in plant geography, both in the scientific and practical sense.

The age of the phytobiota of the Kremenets Mountains National Nature Park can be attributed to the middle Miocene. Already in the lower Tortonian, the ecologically determined development of the flora proceeded in the direction of creo- and xerophytization. In the Upper Miocene and at the beginning of the Pliocene, a dissected landscape with forest-steppe vegetation was formed.

By the middle of the Pliocene, the forest-steppe flora in the region was replaced by the steppe flora, and calceopetrophyton developed. The next mesophytization of the climate, the invasion of the coreal flora forced the plant remains of the favorable period to migrate to the storages - steep, heavily projected slopes with a calcium substrate. The Pliocene was characterized by the development of the calceo-xeromorphic complex with the transformation of the ancient subtropical-forest complex into a modernized xeromesophytic temperate forest complex. During the Pleistocene, the flora 
underwent several periods of cooling and warming. The results of studying the genesis of the flora indicate that during the Pleistocene, under conditions of a dissected relief, there were constant changes in the ecological conditions of a microrefugium nature, which contributed to the preservation of many ancient species [10].

During the last millennium, two complexes of adventive plants have been formed: archaeo- and neophytes. Endemic species of different ages were formed on the basis of the autochthonous nucleus.

The leading genesis complexes of flora formed at the end of the Pliocene. Then the nemoral, calceopetrophilic, psamophilic, hydrophilic, savanoid- meadow-steppe flora was formed. After xero-cryophytic transformation during the Pleistocene, a steppe complex is formed, a complex of coniferous and birch forests, which acquired a modern composition in the Holocene [10].

In the studied territories, we identified 32 relics (3.9\% of the total number of species), of which 7 species are tertiary relics, 25 species are glacial and interglacial, and 60 are endemic $(7.2 \%$ of the total). The richest in the number of natural endemic species are the families Orchidaceae - 10 species, Rosaceae - 10 species, Poaceae - 9 species, Lamiaceae - 7 species.

Most of the endemic species are coenoelements of calceopetrophyton, calceopetrophilic meadow-steppe areas, steppe and calceopetrophilic shrub groups. The formation of the main autochthonous core of the flora took place in the depths of the old paleocalcepetrophyton, on the basis of which the main primordial complexes arose: savanoid-meadow-steppe, ancient-steppe, and ancient-shrub. The second basis for the formation of one of the main components of the flora was the prsnemoral and prashrub.

The approximate time of the emergence and formation of paleoendems of the flora of the studied territories refers to the period from the Middle to Upper Miocene and the beginning of the Pleistocene, these are such species as Galium exoletum, Minuartia aucta, Jurinea pachysperma, etc. In their depths appeared: Euphorbia volhynica, Galium besseri, Salvia cremenecensis, Betula klokovii, etc. The group of mesochronoendemics is determined by the period from the beginning of the Pliocene to the middle of the Pleistocene, these include Salvia dumetorum, Chamaecytisus blockianus.

In the group of paleoendemics, the oldest, which have ancient subthetic roots, indicate the connection of our flora in the past with the ancient Mediterranean. Some of the endemics are associated with the deciduous forests of Central Europe.

\section{Conclusions}

The study of the vegetation cover is necessary to maintain the normal functioning and evolution of ecosystems, the stability of biogeochemical processes, the spontaneous development of biota and the preservation of the ecological balance both at the local and global levels.

Both the number and the ratio of florocoenotypes have clear and pronounced forest-steppe features. The meadow- steppe, steppe and calcepetrophilic groupings of the study areas contain a significant number of relict and endemic aboriginal florocenoelements. In the studied territories, there is a significant share of the agro-ruderal florocoenotypes - $20 \%$, which indicates a significant synanthropization of the flora. Now this situation is more and more common in Ukraine.

A general overview of the specificity of the flora of the studied territories indicates its significant heterochronism, heterogeneity, and originality. In the flora of the region, among the prevailing species, neoendemics are manifested, and a number of relics testify to the connection between the modern flora of the ancient flora, the age of which begins from the end of the Tertiary period.

The great natural diversity of ecotopes in the studied territories creates appropriate favorable opportunities for the formation of viable populations of a large number of plant species, very different in their autoecological properties. Such a unique natural ecological situation requires intensifying efforts in the field of protecting the regional environment from ill-conceived anthropogenic interference and creating conditions for the conservation and natural distribution of rare plant species.

\section{References}

1. T. L. Andriienko, V. S.Tkachenko, V. A. Onyshchenko, UBJ, 55, 3, 311-315 (1998)

2. S.M. Stoiko, I.B. Koinova, UGJ, 1, 50-57 (2012)

3. K. Falinska, Plant ecology (3 dodr., Warsaw, 2012), p.512

4. Ya. P. Didukh, Ekoflora Ukrainy. T. 1-5 (Ecoflora of Ukraine. Part 1-5). (Phytosocial Center, Kyiv, 20002007)

5. I.D. Andriivskyi, Yu. R. Sheliah-Sosonka, Pryrodno-resursnyi aspekt rozvytku Ukrainy (Natural resource aspect of Ukraine's development). (Academia, Kyiv, 2001), pp. 40-75

6. V. I. Melnyk, S. O. Hlinska, Plant introduction, 2, 39 (2010)

7. Litopys pryrody natsionalnoho pryrodnoho parku "Kremenetski hory». T. 2-8 (Chronicle of the nature of the Kremenets Mountains National Nature Park, Part 2-8). (NPP "Kremenets Mountains", Kremenets, 2013-2020)

8. Yu. N. Prokudyn, Opredelitel vyisshih rasteniy Ukrainyi (Keys to higher plants of Ukraine). (Naukova Dumka, Kyiv, 1999), p.546

9. B. V. Zaverukha, Flora Volyino-Podolii i ee genezis (Flora of Volyn-Podolia and its genesis). (Naukova Dumka, Kyiv, 1985), p.191

10. B. V. Zaverukha, Reliktovi ta endemichni roslyny Kremenetskykh hir ta neobkhidnist yikh okhorony. Okhoroniaite ridnu pryrodu. (Relic and endemic plants of the Kremenets Mountains and the need for their protection. Protect your native nature). (Urozhai, Kyiv, 1965), pp.69-78 